\title{
Pemilihan Moda Transportasi Pematangsiantar menuju Bandara Silangit Dengan Metode Stated Preference
}

\author{
Laskar Laurensius SITINJAK ${ }^{1}$ Charles SITINDAON ${ }^{2 *}$ \\ ${ }^{1}$ Program Studi Teknik Sipil Universitas Katolik Santo Thomas \\ ${ }^{2}$ Staf Pengajar Teknik Sipil Universitas Katolik Santo Thomas
}

\begin{abstract}
This study aims to understand user's mode choice preference between bus and private car in making trip from Pematangsiantar to Silangit Airport. We collected responses from 188 respondents who make the trip between aforementioned route. Majority (36\% and $41 \%$ ) states that tariff is the reason to choose bus, and convenience for private cars respectively. The utility function for choosing bus over car is: $\left(U_{\text {bus-car }}\right)=0.127-0.042 X 1-0.012 X 2-0.019 X 3+0.072 X 4+0.282 X 5$; where: $X_{1}=$ difference in cost, $X_{2}=$ time difference, $X_{3}=$ headway difference, $X_{4}=$ service difference and $X_{5}=$ difference in frequency. This study finds that users mode choice preference is sensitive to the difference in service and frequency. The increase in these two attributes improves probability in choosing bus. Further, the probability of choosing bus is still high if there is no change in cost, time, headway difference of the current condition.
\end{abstract}

Kata kunci: : pemilihan moda, stated preference, sensitivitas

\section{Pendahuluan}

Permintaan transportasi, atau dengan kata lain kebutuhan manusia dan barang akan jasa transportasi, bukanlah merupakan kebutuhan langsung (tujuan akhir yang diinginkan). Sesungguhnya kebutuhan akan jasa transportasi timbul disebabkan oleh adanya keinginan untuk mencapai/memenuhi tujuan lain yang sebenarnya. Jasa transportasi hanyalah media mencapai perantara untuk mencapai tujuan lain dimaksud (Miro, 2005).

Faktor pemilihan moda memegang peranan yang cukup penting. Seseorang yang akan bergerak tentu akan mempertimbangkan banyak hal yaitu apakah pergerakan yang dilakukan menggunakan angkutan pribadi maupun angkutan umum. Dalam menggunakan angkutan tersebut, banyak pilihan moda transportasi yang dapat digunakan. Semua hal tersebut terkait erat dengan berbagai karakteristik baik moda, jenis perjalanan maupun karakteristik dari pelaku perjalanan itu sendiri. Pemilihan moda dapat dikatakan tahap terpenting dalam perencanaan transportasi. Ini karena peran kunci dari angkutan umum dalam berbagai kebijakan transportasi. Tidak seorang pun dapat menyangkal bahwa moda angkutan umum menggunakan ruang jalan jauh lebih efisien dari pada moda angkutan pribadi (Tamin, 2008).

Angkutan umum Mobil Pribadi dan bus mempunyai kelebihan dan kekurangan masingmasing sehingga masyarakat sebagai pengguna moda transportasi mempunyai pilihan tersendiri dalam memilih moda transportasi mana yang akan digunakan.

*penulis korespondensi

e-mail: charles_sitindaon@yahoo.co.id 
Dengan melihat adanya alternatif pemilihan moda angkutan untuk sarana mobilitas penduduk dalam rangka peningkatan pelayanan angkutan umum maka dirasa perlu menganalisis pemodelan terhadap pemilihan moda angkutan umum antara moda bus dengan Mobil Pribadi. Dengan adanya pemodelan pemilihan moda tersebut akan diketahui kecenderungan penumpang dan besarnya permintaan terhadap moda-moda tersebut.

Penulisan ini pendekatan diarahkan pada model disaggregat dengan menggunakan teknik Stated Preference (SP). Stated preference merupakan pendekatan relatif baru dalam penelitian transport, yaitu dengan cara menyampaikan pernyataan pilihan (option) berupa suatu hipotesa untuk dinilai oleh responden. Data yang diperoleh dari responden selanjutnya dianalisa untuk mendapatkan suatu model berupa formulasi yang mencerminkan utilitas individu dalam pemilihan moda. Dibangunnya model ini diharapkan dapat menjadi alat guna menentukan kebijaksanaan strategi pengembangan transportasi angkutan penumpang.

Tujuan Penelitian adalah melakukan identifikasi beberapa faktor yang mempengaruhi pemilihan moda angkutan penumpang pada transportasi angkutan bus dan mobil pribadi. Sehingga dapat ditentukan instrumen survey dengan menggunakan teknik Stated Preference. Selanjutnya mengembangkan model hasil analisis regressi yang menyatakan probabilitas individu dalam hal memilih salah satu dari kedua moda tersebut, serta menguji sensitifitas respons model terhadap perubahan biaya, waktu dan keamanan (Elastisitas Pemilihan Moda).

Ruang lingkup pembahasan mencakup hal-hal sebagai berikut:

a. Mendapatkan karakteristik pelaku perjalanan masing-masing moda Mobil Pribadi dan bus yang melayani rute PematangPematangsiantar - Silangit.

b. Menhasilkan model pemilihan moda yang dapat menjelaskan probabilitas pelaku perjalanan dalam memilih moda transportasi.

Menguji sensitivitas pelaku perjalanan dalam penentuan pemilihan moda apabila dilakukan perubahan terhadap atribut perjalanan seperti : cost, time, frequency, headway, dan service.

\section{Tinjauan Pustaka}

\section{Sistem Transportasi}

Sistem transportasi merupakan gabungan dari dua definisi, yaitu sistem dan transportasi. Sistem adalah suatu bentuk keterikatan dan keterkaitan antara satu variabel dengan variabel lain dalam tatanan yang terstruktur, sedangkan transportasi adalah suatu usaha untuk memindahkan, menggerakkan, mengangkut, atau mengalihkan orang atau barang dari suatu tempat ke tempat lain, dimana di tempat lain objek tersebut lebih berguna atau dapat berguna untuk tujuan-tujuan tertentu.

\section{Komponen Sistem Transportasi}

Dalam pemenuhan kebutuhannya, transportasi sangat diperlukan manusia karena sumber kebutuhan manusia tidak selalu berada pada satu tempat saja, tetapi banyak tempat. Adapun beberapa komponen sistem transportasi yang sangat penting sebagai elemen dasar dalam perencanaan sistem transportasi adalah sebagai berikut :

a. Fasilitas fisik, meliputi jalan raya, jalan rel, bandara, dermaga, dan saluran.

b. Armada angkutan, galangan kapal.

c. Fasilitas operasional, meliputi fasilitas pemeliharaan angkutan, ruang kantor.

d. Lembaga, terdiri dari 2 jenis, yaitu lembaga fasilitas orientasi dan lembaga pengoperasian. Lembaga fasilitas orientasi adalah dasar utama dalam perencanaan, 
perancangan, struktur, pemeliharaan, dan fasilitas pengoperasian. Lembaga pengoperasian adalah dasar keterkaitan dengan pengoperasian armada dalam pelayanan transportasi yang meliputi perusahaan Mobil Pribadi, perusahaan penerbangan, perusahaan kapal, perusahaan truk-truk, dan lain-lain.

e. Strategi pengoperasian, meliputi rute kendaraan, jadwal, dan pengontrol lalu lintas.

\section{Peranan Transportasi}

Transportasi memiliki peranan penting dan strategi dalam pembangunan nasional, mengingat transportasi merupakan sarana untuk memperlancar roda perekonomian, memperkokoh persatuan dan kesatuan serta mempengaruhi hampir semua aspek kehidupan. Pentingnya transportasi sebagai urat nadi kehidupan ekonomi, sosial ekonomi, politik, dan pertahanan keamanan memiliki dua fungsi ganda yaitu sebagai unsur penunjang dan sebagai unsur pendorong. Sebagai unsur penunjang, transportasi berfungsi menyediakan jasa transportasi yang efektif untuk memenuhi kebutuhan berbagai sektor dan menggerakkan pembangunan nasional. Sebagai unsur pendorong, transportasi berfungsi menyediakan jasa transportasi yang efektif untuk membuka daerah-daerah yang terisolasi, melayani daerah terpencil, merangsang pertumbuhan daerah tertinggal dan terbelakang. transportasi memegang peranan yang sangat penting karena melibatkan dan mempengaruhi banyak aspek kehidupan manusia yang saling berkaitan. Semakin lancar transportasi tersebut, maka semakin lancar pula perkembangan pembangunan daerah maupun nasional.

\section{Perumusan Model}

Analisis data rating diperlukan untuk mendapatkan hubungan kuantitatif antara sekumpulan atribut dan respons individu yang diekspresikan kedalam skala semantik. Maka diperlukan hubungan nilai numerik $R_{m}$ pada setiap baris $m=1, \ldots \ldots, M$ dari hasil eksperimen sesuai instrumen data, selanjutnya dirumuskan model linier sebagai berikut:

$$
a_{0}+a_{1} X_{1}+a_{2} X_{2}+\ldots \ldots \ldots \ldots+a_{n} X_{n}=r_{j}
$$

,dimana: $\mathrm{a}_{0}=$ konstanta; $\mathrm{X}_{\mathrm{n}}=$ perbedaan atribut ke-n dari dua kompetisi moda pada option yang ditinjau. $a_{n}=$ koefisien dari $X_{n}$ dan $r_{j}=$ representasi dari transformasi respon individu $\mathrm{j}$, yaitu definisi hubungan antara skala semantik dan skala numerik $\mathrm{R}_{\mathrm{m}}$. Bila kuesioner telah lengkap dan analisis untuk memperoleh nilai variabel tak bebas $\mathrm{R}_{m}$ telah diperoleh dengan prinsip logit biner, maka dengan analisis regressi linier berganda akan dihasilkan nilai $\mathrm{a}_{\mathrm{n}}$.

Terdapat banyak sekali skala numerik yang dapat dihubungkan pada skala respon individu, maka hasil analisisnya (koefisien estimasi, ratio, dan goodness-of-fit model) akan tergantung pada definisi dari $\mathrm{R}_{\mathrm{m}}$, hal ini memberikan isyarat pentingnya memilih skala yang benar. Banyak peneliti menggunakan skala simetris $R_{1}=-2,1972 ; R_{2}=-0,8473 ; R_{3}=0,0000 ; R_{4}=$ 0,$8473 ; R_{5}=2,1972$, yang diperoleh dari transformasi linier logit biner Berkson-Theil pada probabilitas pilihan berikut: 0,$1 ; 0,3 ; 0,5 ; 0,7 ; 0,9$. Skala ini hampir dijadikan standar praktis pada beberapa penelitian transportasi (Bates dan Roberts, 1983; Fowkes dan Tweddle, 1988; Ortuzar dan Garrido, 1991). Dalam penelitian marketing biasanya digunakan skala $1-5$, sepertinya tidak ada konsensus tentang skala mana yang cocok digunakan, menjadikan pentingnya menyelidiki dan menyeleksi skala yang sesungguhnya dapat memberikan hasil efek yang signifikan.

\section{Pendekatan Studi}

Melakukan identifikasi faktor-faktor yang mempengaruhi pemilihan moda dan mempelajari perilaku pemilihan moda angkutan penumpang, khususnya pengguna jasa angkutan Bus dan 
Mobil Pribadi (MP). Dengan dua alternatif moda ini ( $i=$ Bus dan $j=$ Mobil Pribadi), maka model tersebut dikenal sebagai model logit binomial dituliskan sebagai berikut:

$$
\begin{gathered}
P_{B u s}=\frac{\exp ^{U_{B u s}}}{\exp ^{U_{B u s}}+\exp _{M P} U_{\text {IP }}}=\frac{\exp ^{\left(U_{B u s}-U_{M P}\right)}}{1+\exp ^{\left(U_{B u s}-U_{M P}\right)}} \\
P_{M P}=1-P_{B u s}=\frac{1}{1+\exp ^{\left(U_{B u s}-U_{M P}\right)}} \\
\text { dan }
\end{gathered}
$$

Probabilitas bahwa individu memilih kereta api $\left(P_{B u s}\right)$ adalah fungsi perbedaan utilitas antara kedua moda. Dengan menganggap bahwa fungsi utilitas linier, maka perbedaan utilitas dapat diekspresikan dalam bentuk perbedaan dalam jumlah $n$ atribut yang relevan diantara kedua moda, yang dirumuskan sebagai berikut:

$$
U_{B u s}-U_{M P}=a_{0}+a_{1}\left(X_{1_{B u s}}-X_{1_{M P}}\right)+a_{2}\left(X_{2_{B u s}}-X_{2_{M P}}\right)+\ldots+a_{n}\left(X_{n B u s}-X_{n M P}\right)
$$

Analisa pengolahan data diperlukan guna mendapatkan hubungan kuantitatif antara atribut dan respon yang diekspresikan dalam skala semantik dengan rumusan model seperti persamaan (4), dimana $U_{B u s}-U_{M P}$ menyatakan respon individu terhadap pernyataan pilihan, $a_{0}$ adalah konstanta, $a_{1}, a_{2}$, dan $a_{\mathrm{n}}$ adalah koefisien masing-masing atribut yang ditentukan melalui metoda least square dengan multiple linear regression. Dengan cara lain, nilai utilitas sebagai respon individu dapat juga dinyatakan dalam bentuk probabilitas memilih moda tertentu, seperti diberikan pada persamaan berikut:

$$
\operatorname{Ln}\left[\frac{P_{B u s}}{1-P_{B u s}}\right]=a_{0}+a_{1}\left(X_{1 B u s}-X_{1_{M P}}\right)+a_{2}\left(X_{2_{B U s}}-X_{2_{M P}}\right)+\ldots . .+a_{n}\left(X_{n_{B u s}}-X_{n_{M P}}\right)
$$

Sehingga dari persamaan 4 dan 5 dapat dirumuskan bentuk persamaan transformasi linear model logit biner atau dikenal sebagai transformasi Berkson-Theil sebagai berikut:

$$
U_{B u s}-U_{M P}=\operatorname{Ln}\left[\frac{P_{B u s}}{1-P_{B u s}}\right]
$$

Ukuran ststistik digunakan untuk menentukan sifat penting yang menjadi dasar dalam memahami dan meramalkan perilaku, yaitu konsep significance test yang memberikan ukuran tingkat keberartian dari faktor mempengaruhi atau tidak mempengaruhi dan goodness-of-fit yaitu ukuran kesesuaian model (R-square).

Pembahasan mengenai elastisitas pemilihan moda diterapkan pada pendekatan model ini adalah dalam bentuk selisih nilai atribut BUS minus Mobil Pribadi $(\Delta X)$. Rumusan elastisitas langsung (direct elasticity) yaitu elastisitas pemilihan Bus terhadap perubahan selisih nilai atribut ke- $n$ adalah : 


$$
\frac{E_{B u s}}{\left(X_{n_{B u s}}-X_{n_{M P}}\right)}=a_{n}\left[\left(X_{n_{B u s}}-X_{n_{M P}}\right)\left(1-P_{B u s}\right)\right]
$$

dan rumusan elastisitas silang (cross elasticity) yaitu elastisitas pemilihan truk terhadap perubahan selisih nilai atribut ke- $n$ adalah sebagai berikut:

$$
\frac{E_{M P}}{\left(X_{n_{B u s}}-X_{n_{M P}}\right)}=-a_{n}\left[\left(X_{n_{B u s}}-X_{n_{M P}}\right) \cdot P_{B u s}\right]
$$

Kedua nilai elastisitas ini digunakan untuk mengetahui prosentase perubahan didalam probabilitas memilih masing-masing moda, sebagai hasil dari perubahan prosentase berubahnya nilai selisih atribut kedua moda tersebut.

\section{Metodologi}

Metode penelitian yang digunakan adalah deskriptis analitis yaitu menggambarkan suatu peristiwa kemudian melakukan analisis masalah yang timbul. Teknik pengumpulan data yang dipakai adalah wawancara atau kuesioner dengan metode stated preference. Dalam penelitian ini, peristiwa yang akan diselidiki hubungannya adalah pemilihan moda bus dan Mobil Pribadi pada trayek Pematangsiantar-Silangit. Sedangkan variabel-variabel yang akan diteliti adalah atribut-atribut internal pelayanan moda dan probabilitas pemilihan moda bus dan Mobil Pribadi yang mengacu pada faktor-faktor yang mempengaruhi pemilihan moda. Teknik stated preference adalah teknik kuesioner dengan membuat alternatif situasi perjalanan hipotesis yang merupakan kombinasi perubahan atribut-atribut pelayanan kedua moda tersebut, lalu diujikan kepada responden dengan cara penyebaran kuesioner untuk mengetahui respon dari penumpang terhadap situasi perjalanan eksperimen tersebut.

\section{Analisis dan Pembahasan}

\section{Karakteristik Pengguna Moda}

Pengguna moda Bus dan Mobil pribadi yang melakukan perjalanan dari Pematangsiantar ke Silangit.

Tabel 1 Distribusi Pengguna Moda Mobil pribadi dan Bus Rute Pematangsiantar - Silangit

\begin{tabular}{|l|l|l|l|}
\hline No & Responden pengguna & Jumlah & Persentase (\%) \\
\hline 1 & Bus & 102 & 54 \\
\hline 2 & Mobil pribadi & 86 & 46 \\
\hline Jumlah & 188 & 100 \\
\hline
\end{tabular}

Berdasarkan distribusi pengguna moda, dilihat kondisi dan karakteristiknya yaitu sebagai berikut:

a. Jenis Kelamin

Distribusi jenis kelamin pengguna moda angkutan dapat dilihat pada Tabel 2 
Tabel 2 Distribusi Jenis Kelamin Pengguna Moda Bus dan Mobil pribadi Rute Pematangsiantar - Silangit

\begin{tabular}{|l|l|l|l|l|l|}
\hline \multirow{2}{*}{ No } & \multirow{2}{*}{ Jenis Kelamin } & \multicolumn{2}{l|}{ Bus } & \multicolumn{2}{l|}{ Mobil Pribadi } \\
\cline { 3 - 6 } & & Jumlah & Persentase & Jumlah & Persentase \\
\hline 1 & Pria & 45 & 44 & 49 & 57 \\
\hline 2 & Wanita & 57 & 56 & 37 & 43 \\
\hline \multicolumn{2}{|l|}{ Jumlah } & 102 & 100 & 86 & 100 \\
\hline
\end{tabular}

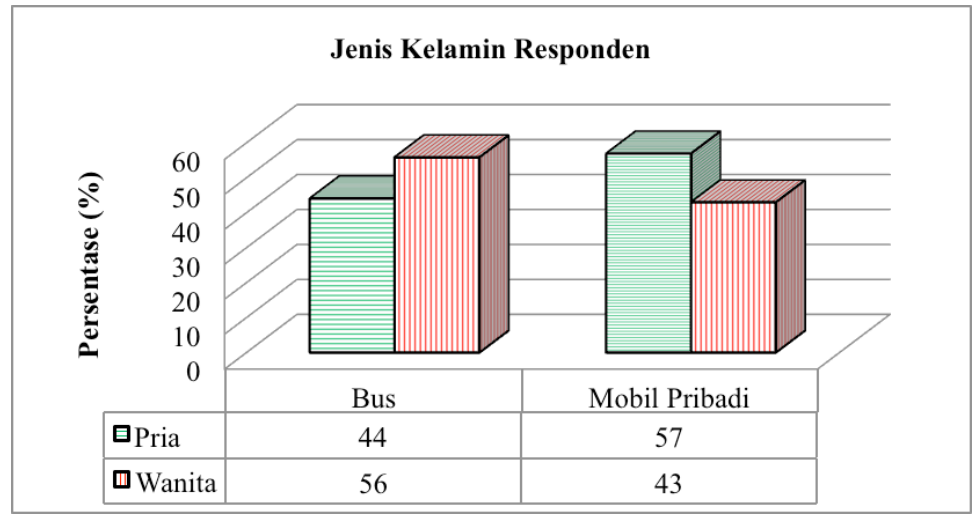

Gambar 1 Distribusi Berdasarkan Jenis Kelamin.

Pengguna moda Bus lebih banyak berjenis kelamin Wanita, yaitu sebanyak 57 orang (56\% dari total jumlah di bus). Hal ini dimungkinkan karena pria lebih mengutamakan kemudahan aksesibilitas dalam melakukan kegiatan sehari-hari. Sedangkan pada moda mobil pribadi lebih banyak berjenis kelamin Pria, yaitu sebanyak 49 orang (57\% dari total jumlah responden di mobil pribadi). Hal ini dimungkinkan karena wanita lebih memilih kenyamanan dalam perjalanannya dimana mereka tidak perlu mengeluarkan tenaga dan pikiran dibandingkan apabila mengendarai kendaraan pribadi dan karena tidak adanya pilihan terhadap moda lain.

b. Usia

Tabel 3 Distribusi Usia Pengguna Moda Bus dan Mobil pribadi Rute Pematangsiantar - Silangit

\begin{tabular}{|l|l|l|l|l|l|}
\hline \multirow{2}{*}{ No } & \multirow{2}{*}{ Usia } & \multicolumn{2}{l|}{ Bus } & \multicolumn{2}{l|}{ Mobil Pribadi } \\
\cline { 3 - 6 } & & Jumlah & Persentase & Jumlah & Persentase \\
\hline 1 & $20-30$ tahun & 12 & 12 & 26 & 30 \\
\hline 2 & $31-40$ tahun & 22 & 22 & 37 & 43 \\
\hline 3 & $41-50$ tahun & 37 & 36 & 19 & 22 \\
\hline 4 & $51-60$ tahun & 31 & 30 & 4 & 5 \\
\hline \multicolumn{2}{|l|}{ Jumlah } & 102 & 100 & 86 & 100 \\
\hline
\end{tabular}




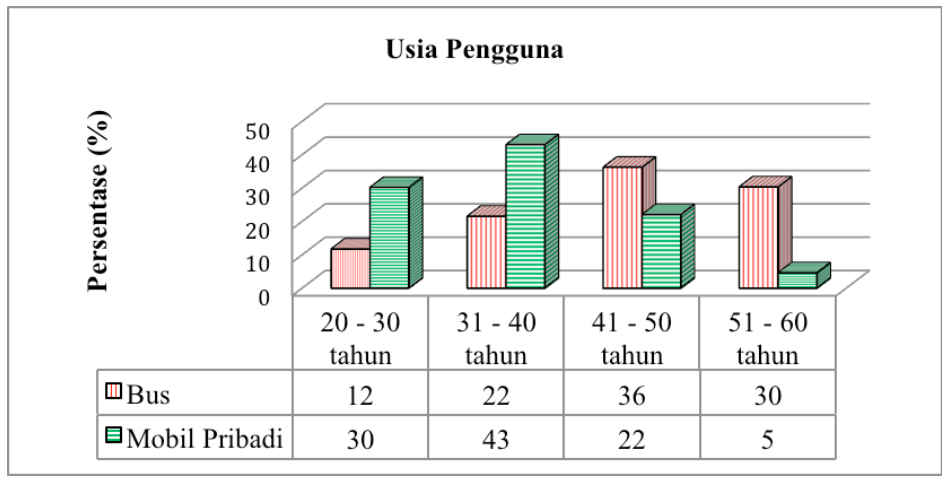

Gambar 2 Distribusi Berdasarkan Usia.

Mayoritas pengguna moda angkutan Bus berada pada masing-masing rentang 41-50 tahun sebanyak 37 orang ( $36 \%$ dari total jumlah responden pengguna bus) dan rentang $31-40$ tahun sebanyak 37 orang (43\% dari total jumlah pengguna mobil pribadi). Hal ini dapat dimungkinkan pengguna dominan adalah pada usia yang sudah bekerja dan sibuk untuk aktifitas sehari-hari.

c. Tingkat pendidikan responden

Distribusi tingkat pendidikan pengguna moda angkutan dapat dilihat pada Tabel 4.

Tabel 4 Distribusi Tingkat Pendidikan Terakhir Pengguna Moda Bus Dan Mobil pribadi

\begin{tabular}{|l|l|l|l|l|l|}
\hline \multirow{2}{*}{ No } & \multirow{2}{*}{ Pendidikan Terakhir } & \multicolumn{2}{|l|}{ Bus } & \multicolumn{2}{l|}{ Mobil Pribadi } \\
\cline { 3 - 6 } & & Jumlah & Persentase & Jumlah & Persentase \\
\hline 1 & SMA & 53 & 52 & 26 & 30 \\
\hline 2 & DIPLOMA & 30 & 29 & 19 & 22 \\
\hline 3 & SARJANA (S1) & 19 & 19 & 41 & 48 \\
\hline Jumlah & 102 & 100 & 86 & 100 \\
\hline
\end{tabular}

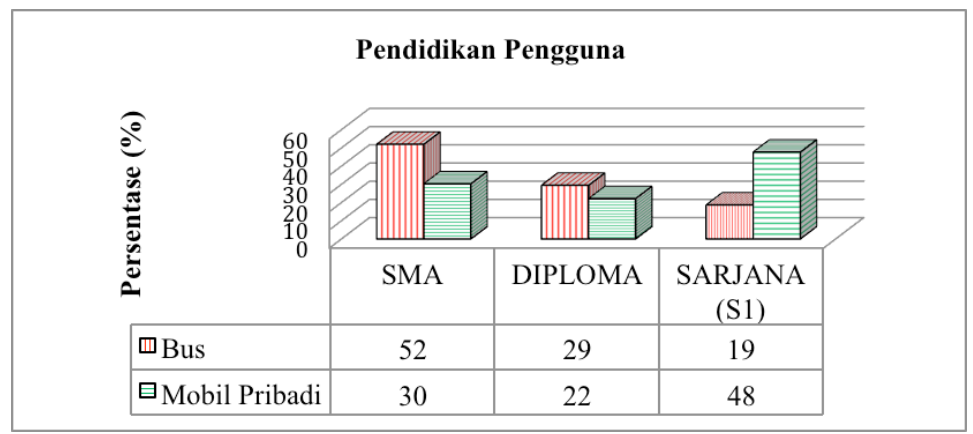

Gambar 3 Distribusi Berdasarkan Pendidikan

Pengguna moda angkutan Bus didominasi oleh responden dengan latar belakang pendidikan SMA sebanyak 53 orang (52\% dari total pengguna angkutan bus).sedangkan moda mobil Pribadi didominasi oleh responden dengan latar belakang pendidikan Sarjana sebanyak 41 orang ( $48 \%$ dari total pengguna mobil). Pengguna dengan pendidikan terakhir SMA cukup dominan hal ini disebabkan pekerjaannya kebanyakan sebagai pekerja dengan penghasilan menengah dan mahasiswa. 


\section{d. Pekerjaan Pengguna}

Distribusi pekerjaan dari pengguna moda angkutan dapat dilihat pada Tabel 5.

Tabel 5. Distribusi Pekerjaan Pengguna Moda Bus dan Mobil pribadi

\begin{tabular}{|l|l|l|l|l|l|}
\hline \multirow{2}{*}{ No } & \multirow{2}{*}{ Pekerjaan } & Bus & \multicolumn{2}{l|}{ Mobil Pibadi } \\
\cline { 3 - 6 } & & Jumlah & Persentase (\%) & Jumlah & Persentase (\%) \\
\hline 1 & PNS & 6 & 6 & 2 & 2 \\
\hline 2 & Petani & 32 & 31 & 5 & 6 \\
\hline 3 & Swasta & 21 & 21 & 15 & 17 \\
\hline 4 & Wiraswasta & 17 & 17 & 33 & 38 \\
\hline 5 & Guru/Dosen & 0 & 0 & 2 & 2 \\
\hline 6 & Pelajar/Mahasiswa & 16 & 16 & 12 & 14 \\
\hline 7 & Lainnya & 10 & 10 & 17 & 20 \\
\hline \multicolumn{2}{|l|}{ Jumlah } & 102 & 100 & 86 & 100 \\
\hline
\end{tabular}

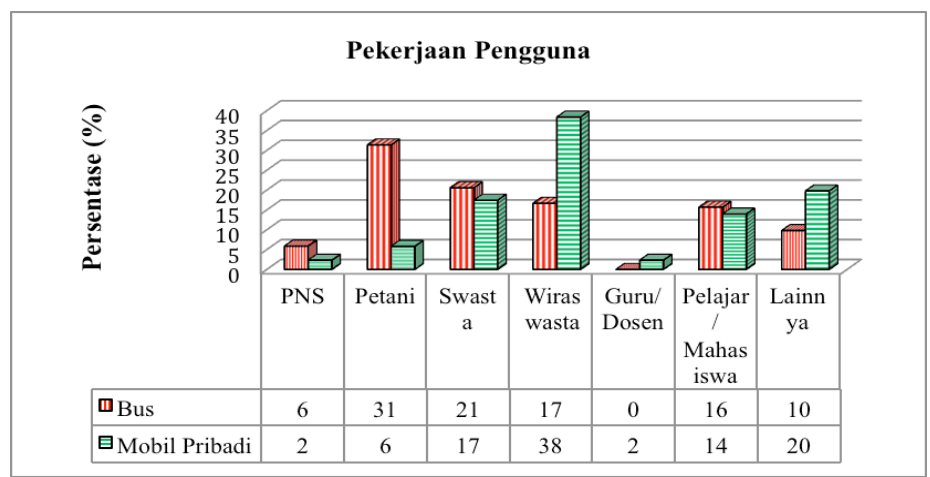

Gambar 4 Distribusi Berdasarkan Pekerjaan

Pengguna moda angkutan bus didominasi oleh responden dengan pekerjaan petani yaitu sebanyak 32 orang (sebesar 31\% dari persentasi keseluruhan bus). Sedangkan pengguna Mobil pribadi lebih banyak sebagai wiraswasta sebanyak 33 orang sebesar $38 \%$. Hal ini dikarenakan pada umumnya petani belum memiliki kendaraan pribadi karena belum pastinya penghasilan sendiri sehingga termasuk kedalam perjalanan tidak memiliki pilihan moda lain selain angkutan kota.

\section{e. Tujuan Perjalanan}

Distribusi tujuan perjalanan pengguna moda angkutan dapat dilihat pada Tabel 6 .

Tabel 6. Distribusi Tujuan Perjalanan Pengguna Moda Bus Dan Mobil Pribadi

\begin{tabular}{|l|l|l|l|l|l|}
\hline \multirow{2}{*}{ No } & \multirow{2}{*}{ Tujuan Perjalanan } & Bus & \multicolumn{2}{l|}{ Mobil Pribadi } \\
\cline { 3 - 6 } & & Jumlah & Persentase & Jumlah & Persentase \\
\hline 1 & Bekerja/Bisnis & 8 & 8 & 21 & 24 \\
\hline 2 & Pendidikan & 12 & 12 & 1 & 1 \\
\hline 3 & Berbelanja & 31 & 30 & 23 & 27 \\
\hline 4 & Berlibur & 22 & 22 & 22 & 26 \\
\hline 5 & Lain-lain & 29 & 28 & 19 & 22 \\
\hline Jumlah & 102 & 100 & 86 & 100 \\
\hline
\end{tabular}




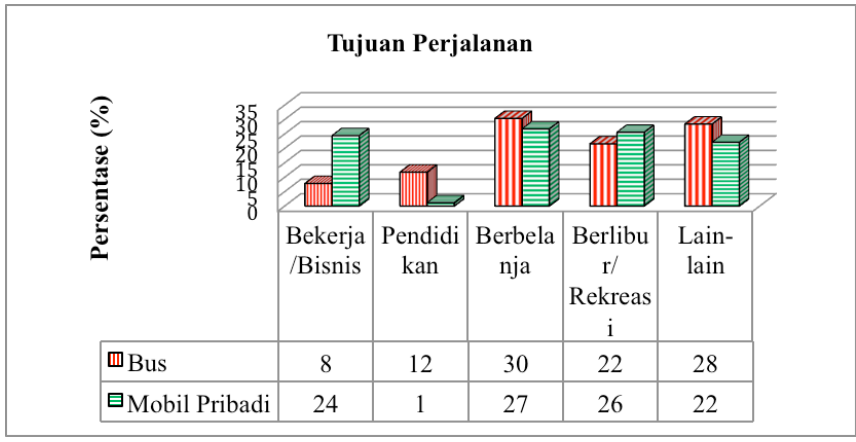

Gambar 5 Distribusi Berdasarkan Tujuan Perjalanan

Pengguna moda angkutan bus didominasi oleh responden dengan tujuan perjalanan berbelanja yaitu 31 orang (30\% dari total pengguna angkutan umum bus) dan pengguna moda angkutan Mobil Pribadi 23 orang (27\% dari total responden pengguna mobil pribadi).

\section{f. $\quad$ Tingkat Penghasilan Per Bulan}

Distribusi tingkat penghasilan dari pengguna moda angkutan dapat dilihat pada Tabel 7.

Tabel 7 Distribusi Tingkat Penghasilan Pengguna Moda Bus Dan Mobil pribadi

\begin{tabular}{|l|l|l|l|l|l|}
\hline \multirow{2}{*}{ No } & \multirow{2}{*}{ Tingkat Penghasilan per Bulan } & \multicolumn{2}{l|}{ Bus } & \multicolumn{2}{l|}{ Mobil Pribadi } \\
\cline { 3 - 6 } & & Jumlah & Persentase & Jumlah & Persentase \\
\hline 1 & $<$ Rp 1.500.000,00 & 27 & 26 & 3 & 3 \\
\hline 2 & Rp 1.500.000,00 - Rp 2.500.000,00 & 34 & 33 & 22 & 26 \\
\hline 3 & Rp 2.500.000,00 - Rp 3.500.000,00 & 26 & 25 & 28 & 33 \\
\hline 4 & $>$ Rp 3.500.000,00 & 15 & 15 & 33 & 38 \\
\hline Jumlah & 102 & 100 & 86 & 100 \\
\hline
\end{tabular}

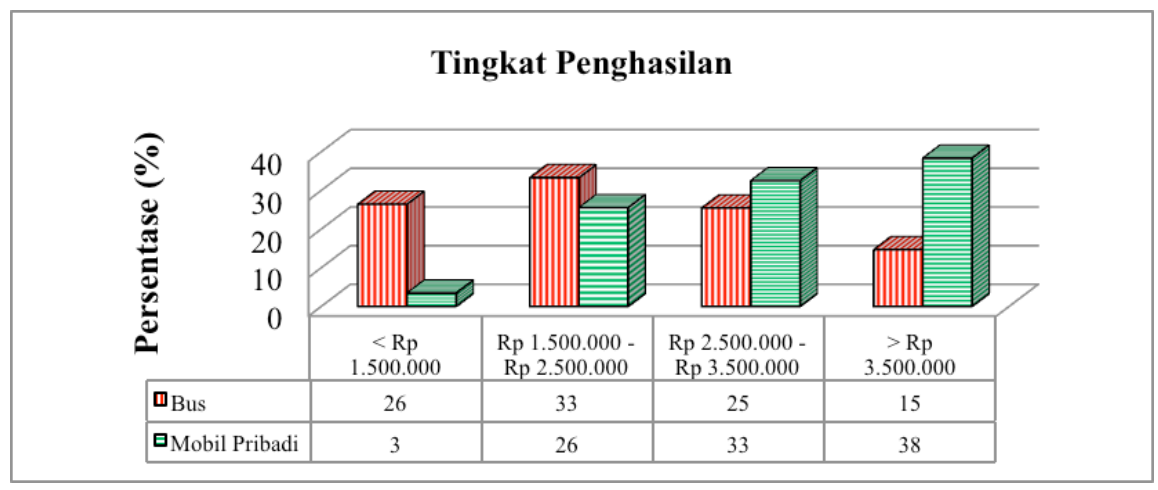

Gambar 6 Distribusi Berdasarkan Penghasilan

Pengguna lebih dominan moda angkutan bus dengan berpenghasilan Rp 1.500.000,00 Rp 2.500.000,00 sebanyak 34 orang (33\% dari total responden pengguna angkutan bus) dan mobil pribadi berpenghasilan > Rp.3.500.000,00 sebanyak 33 orang ( $38 \%$ dari total responden pengguna mobil pribadi) 
g. Alasan memilih moda

Distribusi alasan memilih moda dari responden pengguna moda angkutan dapat dilihat pada Tabel.8

Tabel 8. Distribusi Alasan Memilih Moda Bus Dan Mobil pribadi

\begin{tabular}{|l|l|l|l|l|l|}
\hline \multirow{2}{*}{ No } & \multirow{2}{*}{ Alasan Memilih Moda } & \multicolumn{2}{l|}{ Bus } & \multicolumn{2}{l|}{ Mobil Pribadi } \\
\cline { 3 - 6 } & & Jumlah & Persentase & Jumlah & Persentase \\
\hline 1 & Kecepatan/Waktu & 9 & 9 & 26 & 30 \\
\hline 2 & Harga/Tarif & 37 & 36 & 0 & 0 \\
\hline 3 & Keselamatan & 15 & 15 & 19 & 22 \\
\hline 4 & Kemudahan/Mobilitas & 35 & 34 & 6 & 7 \\
\hline 5 & Kenyamanan & 6 & 6 & 35 & 41 \\
\hline \multicolumn{2}{|l|}{ Jumlah } & 102 & 100 & 86 & 100 \\
\hline
\end{tabular}

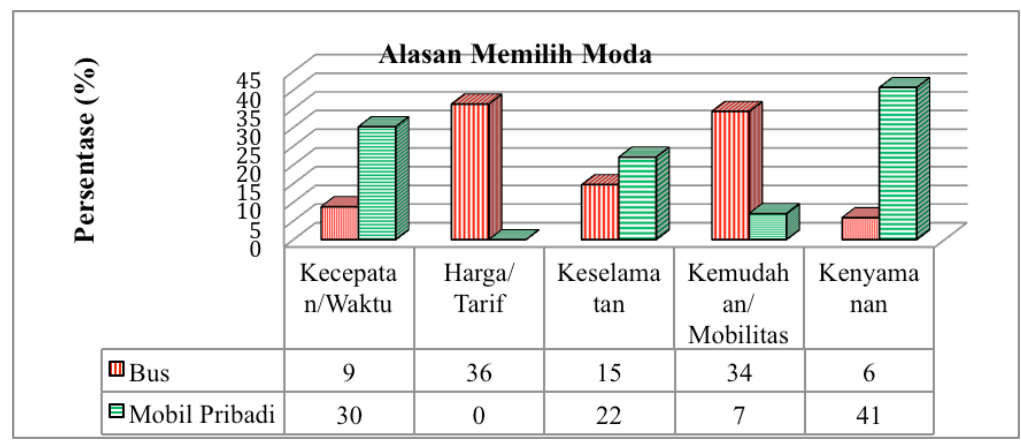

Gambar 8 Distribusi Berdasarkan Alasan Memilih

Alasan memilih moda diketahui bahwa pengguna moda BUS paling banyak dengan alasan tarif yaitu sebesar 37 orang ( $36 \%$ dari total pengguna angkutan bus). Karena keunggulan dari angkutan umum bus adalah harga yang lebih ekonomis, Sedangkan pada pengguna moda mobil pribadi alasan kenyamanan yaitu sebanyak 35 orang (41\% dari total responden pengguna mobil pribadi).

\section{Analisis Pendekatan Model}

Urutan untuk memeriksa permasalahan model estimasi dengan menggunakan tipe respon skala yang berbeda yaitu variabel tak bebas, diputuskan untuk melakukan test terhadap dua analisis model pendekatan:

a. REG-1 ; Model Linier Regressi (LR), dimana skala respon adalah transformasi BerksonTheil dari urutan $\mathrm{R}_{\mathrm{m}}=\{0,1 ; 0,3 ; 0,5 ; 0,7 ; 0,9\}$. Ini telah terpilih karena sudah banyak digunakan beberapa studi rating stated preference pada penelitian transportasi (Bates and Roberts, 1983 ; Fowkes and Tweddle, 1988; Ortuzar and Garrido, 1991).

b. REG-2 ; Model Linier Regressi (LR), skala respon ditentukan selama proses memaksimalkan goodness of fit model $\left(\mathrm{r}^{2}\right)$, secara efektif mempertimbangkan setiap nilai skala $\left(\mathrm{R}_{1}, \mathrm{R}_{2}, \ldots, \mathrm{R}_{5}\right)$ sebagai variabel tambahan. Nilai $\mathrm{r}^{2}$ yang optimum digunakan metode koordinasi pemeriksaan (coordinate search method), dimulai dari nilai skala pada REG-1. 


\section{Pengembangan Model}

Hasil data yang terkumpul, maka penelitian ini menghasilkan model berdasarkan moda angkutan penumpang Bus dan Mobil Pribadi. Input data adalah nilai variabel bebas yang merupakan selisih besaran atribut kedua moda dan variabel terikat yaitu respon pilihan berupa nilai skala point rating baik REG-1 maupun REG-2, maka dengan bantuan perangkat lunak Microsof Exel/Program SPSS, dilakukan analisa regressi untuk mendapatkan koefisien dan parameter model serta nilai uji statistik. Dengan langkah regressi yang dilakukan berulangkali, nilai skala optimum untuk model yang akan dikembangkan dapat diperoleh.

Model yang dikembangkan melalui dua pendekatan (REG-1, REG-2), sehingga pendekatan tersebut akan menghasilkan $r$-square maksimum yang selanjutnya diperoleh model.

$\left(\mathrm{U}_{\text {Bus }- \text { mobil pribadi }}=0,127-0,042 \mathrm{X}_{1}-0,012 \mathrm{X}_{2}-0,019 \mathrm{X}_{3}+0,072 \mathrm{X}_{4}+0,282 \mathrm{X}_{5}\right.$

dengan $\mathrm{R}^{2}=0,515$ dan $\mathrm{F}=896,707$

Dimana: $\mathrm{X}_{1}=$ Selisih cost antara Bus dan Mobil pribadi; $\mathrm{X}_{2}=$ Selisih time antara Bus dan Mobil pribadi; $\mathrm{X}_{3}=$ Selisih headway antara Bus dan Mobil pribadi; $\mathrm{X}_{4}=$ Selisih service antara Bus dan Mobil pribadi; $\mathrm{X}_{5}=$ Selisih frequency antara Bus dan Mobil pribadi; $\mathrm{Y}=$ Nilai Utilitas

Berikut ini ditampilkan grafik pemilihan moda yang merupakan hubungan antara probabilitas pemilihan moda dengan selisih utilitas bus dan mobil pribadi.

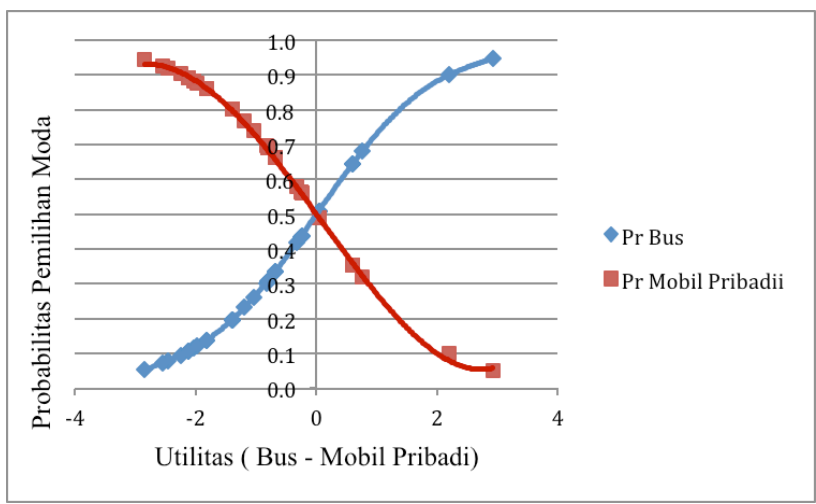

Gambar 9 Besarnya Utilitas dan Probabilitas Pemilihan Moda

Berdasarkan pemilihan moda Bus dan Mobil Pribaadi dari PematangPematangsiantar menuju Bandara Silangit, diperoleh : Bila Utilitas 0 ( Bus - Mobil Pribadi) probabilitas pemilihan moda seimbang di 50\%, Utilitas 1 (Bus - Mobil Pribadi) probabilitas pemilihan moda Bus di $70 \%$ sedangkan mobil ribadi $30 \%$. Bila selisih nilai utilitas antara bus dan mobil pribadi meningkat, maka probabilitas terpilihnya bus akan semakin meningkat sedangkan probabilitas mobil pribadi akan menurun. Sedangkan selisih nilai utilitas antara bus dan mobil pribadi menurun, maka probabilitas bus akan semakin menurun sedangkan probabilitas mobil pribadi akan meningkat. 


\section{Analisis Sensitifitas}

1. Sensitivitas Terhadap Atribut Ongkos

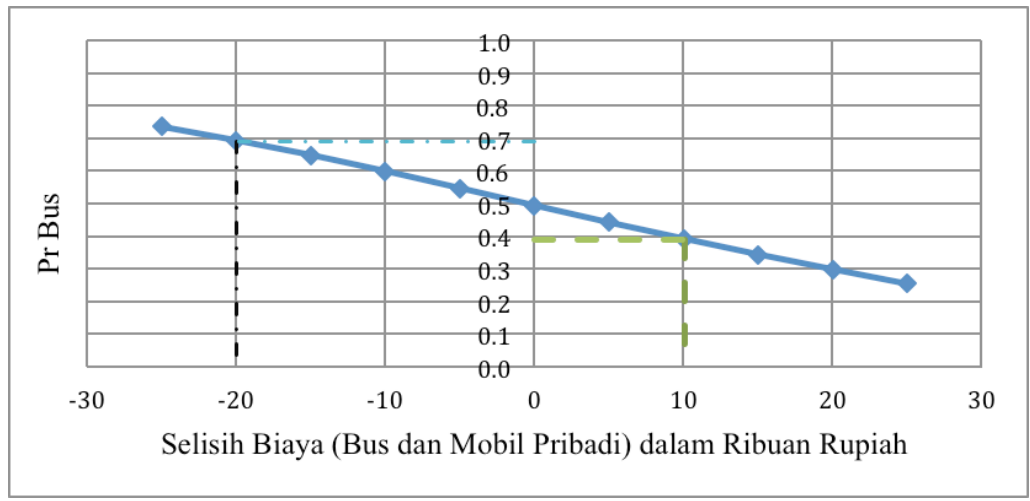

Gambar 10 Sensitifitas Terhadap Ongkos

Bila biaya perjalanan bus sebesar Rp 45.000 dan biaya perjalanan mobil pribadi sebesar Rp 60.000 maka probabilitas Bus sebesar 65\%. Jika selisih ongkos di perbesar menjadi 20 memberikan peluang bus meningkat menjadi $70 \%$, sedangkan saat mobil pribadi dikurangi sebanyak 10 memberikan efek yang besar pada bus menurun menjadi $40 \%$. Untuk meningkatkan probabilitas Bus maka biaya perjalanan bus dikurangi sebesar Rp 5.000 sedangkan biaya perjalanan mobil pribadi tetap. Maka probabilitas Bus meningkat menjadi $69.35 \%$.

\section{Sensitivitas Terhadap Atribut Waktu Tempuh Perjalanan}

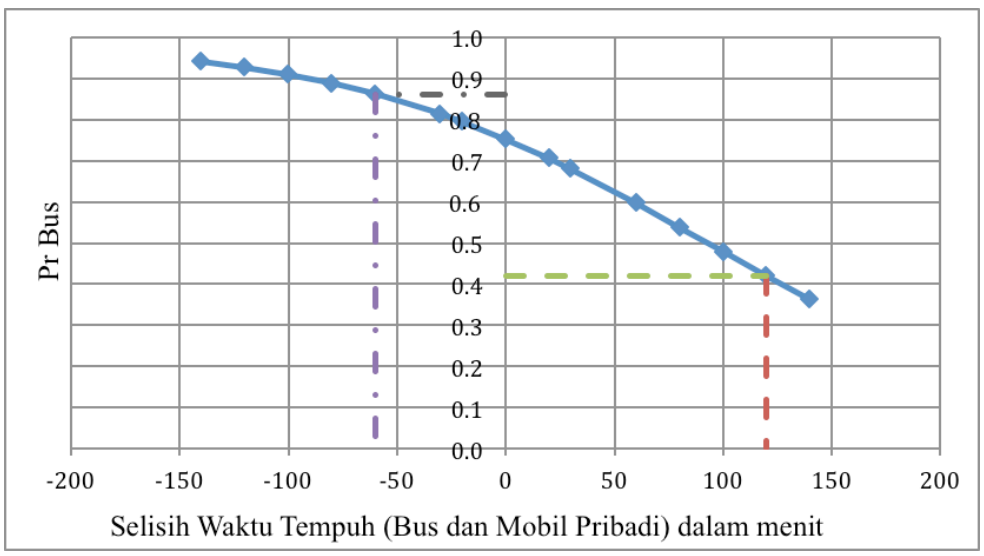

Gambar 11 Sensitifitas Terhadap waktu Perjalanan

Waktu tempuh perjalanan bus dan mobil pribadi sama yaitu selama 3,5 jam (210 menit) maka probabilitas bus sebesar $75 \%$. Waktu tempuh bus di tingkatkan menjadi 60 menit lebih cepat memberikan efek peluang bus menjadi $86 \%$, tetapi saat bus diperlambat 60 menit memiliki sensitifitas yang cukup besar yaitu 59\% sangat jauh turun dari saat stabil $75 \%$, tentu jika di lihat dari karakternya bus sangat sensitif kepada negatif jika ada suntikan dari mobil pribadi. Untuk meningkatkan probabilitas Bus maka waktu tempuh perjalanan bus harus lebih cepat dibandingkan waktu tempuh perjalanan mobil pribadi. 


\section{Sensitivitas Terhadap Atribut Headway}

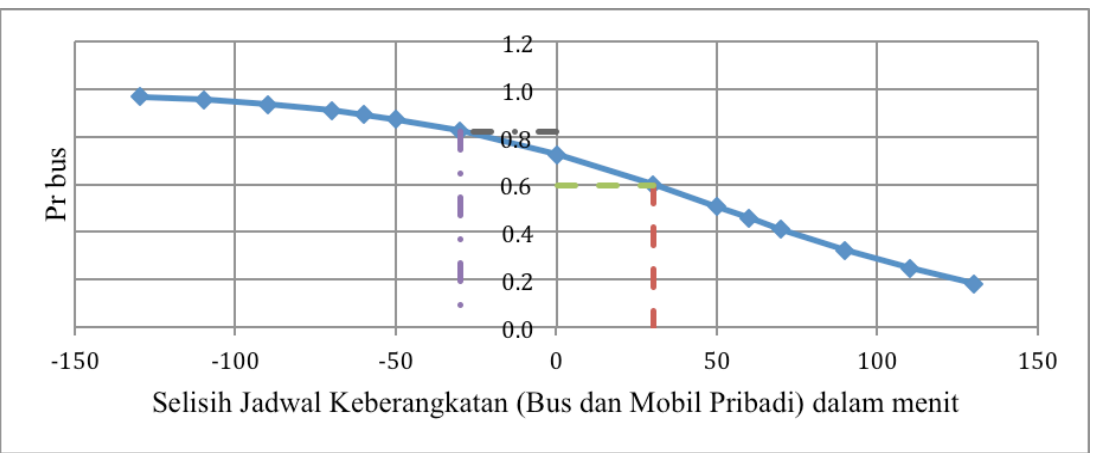

Gambar 12 Sensitifitas Terhadap Headway

Jadwal keberangkatan Bus dan Mobil Pribadi sama yaitu 1 unit per jam maka probabilitas bus sebesar $72 \%$. Keberangkatan Bus ditingkat menjadi setiap 30 menit dan jadwal keberangkatan mobil pribadi tetap maka probabilitas bus naik $82 \%$. Untuk meningkatkan probabilitas bus maka jadwal keberangkatan per harinya lebih sering dibandingkan jadwal keberangkatan mobil pribadi. Dimana jadwal keberangkatan bus tiap 30 menit

\section{Sensitivitas Terhadap Atribut Pelayanan (Service)}

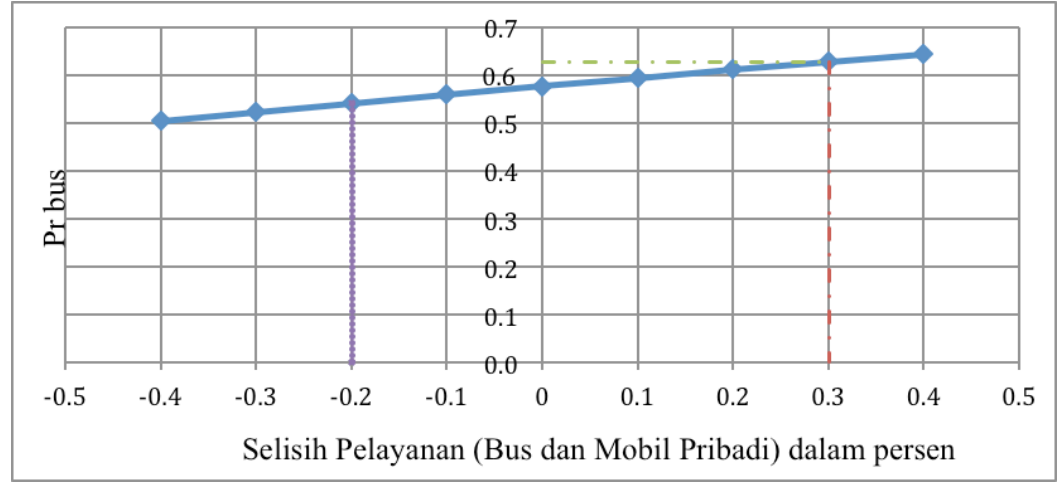

Gambar 13 Sensitifitas Terhadap Pelayanan

Bila selisih Pelayanan perjalanan Bus dan mobil pribadi $20 \%$ maka probabilitas bus sebesar 55\%. Kondisi pelayanan sama antara bus dan mobil pribadi memberikan peluang bus $57 \%$, kemudian saat pelayanan bus lebih unggul dengan memberikan fasilitas yang memadai maka peluang bus sebesar $63 \%$.

\section{Sensitivitas Terhadap Atribut Frekuensi Perjalanan}

Bila frekuensi perjalanan bus dan mobil pribadi sama yaitu 18 kali per hari maka probabilitas bus sebesar $46 \%$. Frekuensi selisih perjalan bus sebesar 3 kali lebih banyak maka probabilitas bus naik sebesar $66 \%$, namun yang menjadi perhatian berdasarkan karakter grafik diatas saat bus mengalami penurunan sebanyak 3 kali memberikan sensitifitas kearah negatif yaitu sebesar $26 \%$, ini menjadi perhatian jika ditinjau dari resiko akan kegagalan dalam mengambil keputusan. 


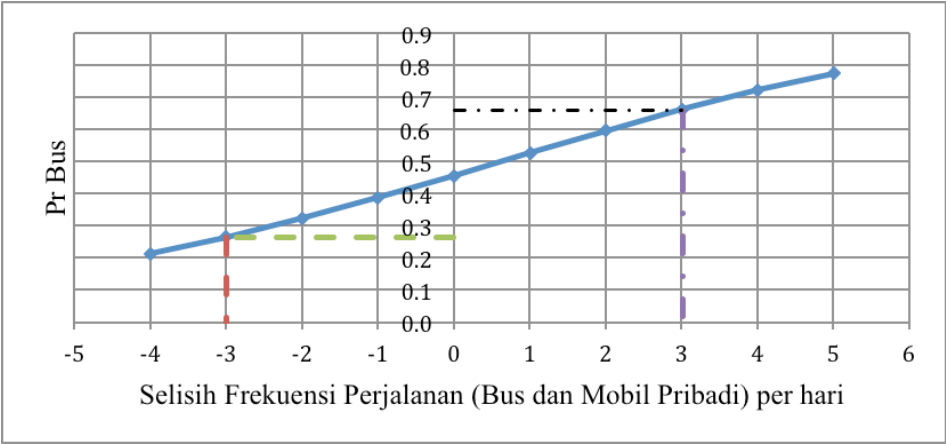

Gambar 9 Sensitifitas Terhadap Frekuensi

\section{Kesimpulan dan Saran}

\section{Kesimpulan}

Hasil analisis pemilihan moda angkutan penumpang antara Bus dan Mobil Pribadi dari PematangPematangsiantar menuju Bandara Silangit, adalah :

1. Karakteristik umum pengguna dalam pemilihan moda sebagai berikut:

a. Jenis kelamin pengguna moda Bus lebih didominasi oleh Wanita sebesar 56\% dan pengguna moda Mobil Pribadi didominasi oleh Pria sebesar 57\%.

b. Usia pengguna moda bus berusia 41-50 tahun masing-masing 36\% dan mobil pribadi usia 31-40 tahun sebesar $43 \%$.

c. Pendidikan terakhir pengguna moda bus didominasi SMA 52\% dan mobil pribadi $48 \%$.

d. Pekerjaan pengguna moda bus didominasi petani sebesar $31 \%$ dan Sedangkan pada Mobil Pribadi didominasi Wiraswasta sebesar 38\%.

e. Maksud perjalanan untuk pengguna moda bus adalah untuk berbelanja sebesar $30 \%$ dan mobil pribadi berlibur $27 \%$.

f. Tingkat penghasilan pengguna bus Rp 1.500 .000 -Rp 2.500 .000 yaitu sebesar $33 \%$. dan mobil pribadi Rp 3.500 .000 sebesar 38\%.

g. Alasan memilih moda karena harga/tarif sebesar $36 \%$ dan pengguna moda Mobil Pribadi alasan kenyamanan $41 \%$.

2. Model pemilihan moda angkutan penumpang antara bus dan mobil pribadi adalah: $\mathrm{U}_{\text {bus }}-\mathrm{U}_{\text {mobil pribadi }}=0,127-0,042 \mathrm{X}_{1}-0,012 \mathrm{X}_{2}-0,019 \mathrm{X}_{3}+0,072 \mathrm{X}_{4}+0,282 \mathrm{X}_{5}$; Dimana : $\mathrm{X}_{1}=$ selisih cost, $\mathrm{X}_{2}=$ selisih time, $\mathrm{X}_{3}=$ selisih headway, $\mathrm{X}_{4}=$ selisih service dan $\mathrm{X}_{5}=$ selisih frequency.

3. Sensitivitas pemilihan moda dengan atribut cost, time, headway, service, frequency adalah:

a. Probabilitas memilih bus yang memiliki dampak positif bila selisih atribut service dan frequency semakin besar.

b. Probabilitas memilih bus masih tetap tinggi apabila selisih atribut cost, time, headway masih memakai harga yang terjadi.

\section{Saran}

Hasil penelitian yang dilakukan, ada beberapa saran :

1. Aplikasi yang lebih luas dari teknik stated preference dalam analisis pemilihan moda angkutan penumpang, direkomendasikan untuk menambah jumlah responden pada masing-masing tujuan, untuk mencapai kebutuhan minimal sampel data

2. Analisa pemilihan moda ini tujuan PematangPematangsiantar- Silangit, sebaiknya perlu diperluas untuk menganalisa lebih lanjut pergerakan penumpang yang dari arah 
sebaliknya, Silangit - PematangPematangsiantar, agar penaksiran pergerakan penumpang bus maupun Mobil Pribadi dapat lebih akurat.

3. Atribut perjalanan yang ditinjau dalam penelitian ini, perlu dikaji atribut lain seperti jarak ke bandara, biaya tambahan menuju terminal dan lain-lain. Karena atributatribut tersebut diperkirakan memberikan pengaruh secara signifikan terhadap persepsi penumpang terhadap nilai utilitas, guna memperbesar nilai koefisien determinasi model

\section{Daftar Pustaka}

Bombongan, C. (2014). Analisis Pemilihan Moda Angkutan Umum Rute Medan-Bandara Kuala Namu (Studi Kasus: Kompetisi antara Kereta Api Bandara dan Bus Bandara Koridor 1) (Master's thesis). Diakses dari perpustakaan Universitas Sumatera Utara, Medan

de Dios Ortuzar, J., \& Willumsen, L. G. (2011). Modelling transport. John Wiley \& Sons.

Kroes, E. P., \& Sheldon, R. J. (1988). Stated Preference Methods: An Introduction. Journal of Transport Economics and Policy, 22(1).

Mustaji. (2001). Pemodelan Pemilihan Moda Angkutan Bus dan Mobil Pribadi Kelas Eksekutif Dengan Teknik Stated Preference (Skripsi Sarjana). Diakses dari perpustakaan Jurusan Teknik Sipil, UNS, Surakarta.

Ortuzar, J. D. D., \& Garrido, R. A. (1994). On the semantic scale problem in stated preference rating experiments.Transportation (1986-1998), 21(2), 185.

Panjaitan, I. M. (2012). Pemodelan Pemilihan Moda Angkutan Penumpang Karya Agung \& KBT (Koperasi Bintang Tapanuli) dengan ketepatan Model Probit dan Logit, Studi Kasus: MedanBalige. Pemodelan Pemilihan Moda Angkutan Penumpang Karya Agung \& KBT (Koperasi Bintang Tapanuli) dengan ketepatan Model Probit dan Logit, Studi Kasus: Medan-Balige (Skripsi Sarjana). Diakses dari perpustakaan Universitas Sumatera Utara, Medan.

Pearmain, D., \& Kroes, E. P. (1990). Stated preference techniques: a guide to practice. UK: Steer Davies Gleave \& Hague Consulting Group.

Pramesti, G., \& Si, M. (2015). Kupas tuntas data penelitian dengan SPSS 22. Jakarta: Elex Media Komputindo.

Priyatno, D. (2016). Analisis Data, Olah Data \& Penyelesaian Kasus-Kasus Statistik. Yogyakarta: Mediakom.

Sitindaon, C. (2001). Kajian Model Pemilihan Moda Angkutan Barang Antara Kereta Api dan Truk (Tesis Magister). Diakses dari perpustakaan ITB, Bandung. 